\title{
The Influence of the SAVI Approach and Learning Styles on Student's Creative Math Skills
}

\section{BT Yosi Olda Fionika, Kamid, Evita Anggereini}

\author{
Magister of Mathematic Education \\ Study Program Faculty of Teacher Training Education, Jambi University. \\ btyosioldafionika@gmail.com
}

\begin{abstract}
Learning technique at school should concentrate on developing students creativity. Creative thinking ability will be the determinant of individual success. But in fact, students are familiar with routine and simple learning. The SAVI approach is an approach that combines physical movement with intellectual activity. Learning style is the capital of a student to absorb information. The method used in this research is quantitative method, which is the purpose is to know the influence of SAVI approach and learning style to students' creative thinking ability in mathematics when compared with direct learning. The instruments used are tests of creative thinking abilities and learning styles of students. The result of data analysis using statistical test that is (1) there is influence of SAVI approach and learning style to student creative thinking ability. (2) there is influence of SAVI approach to SAVI creative thinking ability. (3) there is influence of student learning style to student creative thinking ability. (4) there is an interaction between SAVI approach and learning style to students' creative thinking ability.

Keywords: SAVI approach, creative thinking ability, learning style.
\end{abstract}

\section{INTRODUCTION}

Indonesia is a developing country, which still requires creativity of the nation's children to advance science and technology. So, learning in schools should be more emphasis on aspects of student creativity development, so the children are familiar to find creative ways to solve a problem. According to Ali Mahmudi (2009: 1) The ability of creative thinking becomes the determinant of individual success in the face of increasingly complex life challenges. The progress of a nation is no longer determined by how much resources the nation possesses, but how creative the society of a country is.

After the researchers made observations to some students in SMAN 11 jambi city, it was found that students' creative thinking ability is not optimal. Students are familiar to get routine and simple questions which only can be solved in one way or only by using one formula. Therefore, when they are faced with non-routine and varied questions, they are confused in relating mathematical concepts that they already learned to solving the problems. This is due to the activity of teachers who only pursue the learning materials finished in time. The teacher emphasizes that the student must complete the material at 
the targeted meeting. So, reasonable if there are still many students who will solve the problems given by the teacher in a way that the teacher gave.

Involving the activity of all the senses in the learning process is very important and influential. Magnesen (Dryden \& Jeannette, 2013:100) says that in learning 10\% students will capture lessons from what they read, $20 \%$ of what is heard, $30 \%$ of what is seen, $50 \%$ of what is seen and heard, $70 \%$ of what is said, and $90 \%$ of what it does and says. According to Meier, learning with the SAVI approach is a learning that combines physical movement with intellectual activity and the use of all the senses that can have a major effect on learning. The SAVI elements are Somatis (learning by moving and doing), Auditory (learning by speaking and listening), Visual (learning by observing and describing), and Intellectual (learning by solving problems and thinking). It is expected that students learn by moving and doing, learning by speaking, learning by observing and describing and learning by solving a problem will help students in shaping the ability of creative thinking, yangmana in creative thinking ability there are 4 indicators that is smoothness, flexibility, originality and elaboration ( details).

However, in order for learning to be more effective in solving creative thinking problems, it is important to have teacher's knowledge about student learning styles. In fact, students have a variety of modalities that must be optimized in learning in order to obtain maximum results. Some of these modalities as proposed by DePorter are visual modalities, auditorial modalities, and kinesthetic modalities (somatic), known as VAK. The three modalities are factors that influence the learning styles of each student.

Based on the results of research from Aswar and Nilam (2014) entitled "Pengaruh Gaya Belajar VAK terhadap hasil belajar matematika siswa" indicates that there is an influence of learning style of Kinesthetic Visual Auditory to student learning outcomes. The research of learning style is also done by Indrawan Dwi Candra (2015) entitled "Pengaruh Gaya Belajar Terhadap Hasil Belajar Siswa Kelas IV SD Negeri Pajang 3 Surakarta" which indicates that there is a significant influence between learning styles on learning outcomes. Learning styles contributed $11.8 \%$ influence on student learning outcomes. But in this study, researchers only take the data, not doing experiments in the classroom. So the researcher does not know what learning model used by the teacher when teaching that affect student learning outcomes.

Based on the above description, it can be concluded that the students' academic achievement in school is influenced by two factors, namely the factor of the student's self and the factors of his environment. One of the factor from the student's self is the learning style while the factor of the environment is the way of teaching the teacher. Then, one of the efforts considered to solve the problem is by using the approach SAVI (Somatis, Auditory, Visual, Intellectual). The learning no longer benefits only one group of students, but all students with different learning styles are able to receive learning materials according to the way they capture information from the lesson.

Mathematics learning is a process of interaction between teachers and students in an organized form of activity in order to help students to obtain information and knowledge of mathematics. So that students are able to think logically, able to find mathematical patterns, relate connections between patterns and then communicate the knowledge of mathematics both in the form of symbols and oral. 
SAVI stands for Somatis, Auditory, Visual, and Intellectual. The SAVI approach is incorporated into a student-centered approach (Student Centered Approach). Meier (2000: 42) argues that "Learning does not automatically improve by standing up and moving around. But combining physical movement with intellectual activity and the use of all the senses can have a profound effect on learning ". However, combining physical movement with intellectual activity and uses all of the senses can have a major impact on learning. Basic principle of the SAVI approach is learning involves the whole mind and body, so it's not just the brain that works.

Style of learning is the key to developing a performance at work, at school, and in interpersonal situations. In some elementary schools and high schools in America, teachers realize that everyone has the optimal way to learn new information. They understand that some students need to be taught other ways than standard teaching methods. If these students are taught by standard methods, it is possible for them to understand the material is very small. Knowing these different learning styles has helped teachers everywhere to be able to approach all or nearly all students by simply passing on information in different styles.

Prashing (2007: 10) states that "Everyone of all ages can really learn anything if they are allowed to do it in a unique style that suits their own personal strength". it states that if human diversity is considered and taken into consideration in the learning process, it will produce positive results such as learners feel happy, gain the sensation of achieving something without frustration and stress, increasing motivation and always able to control the learning process. In short, one's learning style can be defined as a combination of how one absorbs, then organizes and manages the information or lessons that they learned. Any way someone chooses, the different of learning styles show the fastest and best way for each individual to be able to absorb an information or lesson from outside themself. Each individual has their own learning style that can not be equated and enforced just like everyone else. generally the type of someone's learning style can be classified into three types: visual learning style, auditory learning style, and kinesthetic learning style.

\section{RESEARCH METHOD}

The method used in this research is quantitative method. This type of research is a quasi experiment. Sugiono (2009: 72) "Methods of experimental research can be interpreted as a research method used to find the effect of certain treatment against others in controlled conditions". Research using this experimental method is an activity to examine an event due to a condition that is monitored carefully to determine the effect that appears.

The research design uses Quasi-Experiment Design with the type of pretest and posttest design. The research design according to (Creswell, 2008: 314).

Table 1 Design Quasi Experiments (posttest only design)

\begin{tabular}{cccc}
\hline Group & Pre-test & Treatment & Post-test \\
\hline Exsperimental & $\mathrm{Y}_{1}$ & $\mathrm{X}$ & $\mathrm{Y}_{2}$ \\
Control & $\mathrm{Y}_{1}$ & - & $\mathrm{Y}_{2}$ \\
\hline
\end{tabular}


$\mathrm{X}=$ Treatment given to the experimental class

Y1 = Initial test given to the experimental class and control class at the beginning of the lesson

$\mathrm{Y} 2=$ The final test given to the experimental class and control class at the end of the lesson

The research design using $3 \times 3$ factorial can be seen in the following table:

Table 2 Research Design

\begin{tabular}{llll}
\hline Learning Styles $(\mathrm{B})$ & \multicolumn{3}{c}{ Approach $(\mathrm{A})$} \\
\cline { 2 - 4 } & SAVI $\left(\mathrm{A}_{1}\right)$ & SAVI + Media $\left(\mathrm{A}_{2}\right)$ & $\mathrm{DI}\left(\mathrm{A}_{3}\right)$ \\
\hline Visual $\left(\mathrm{B}_{1}\right)$ & $\left(\mathrm{A}_{1} \mathrm{~B}_{1}\right)$ & $\left(\mathrm{A}_{2} \mathrm{~B}_{1}\right)$ & $\left(\mathrm{A}_{3} \mathrm{~B}_{1}\right)$ \\
Auditori $\left(\mathrm{B}_{2}\right)$ & $\left(\mathrm{A}_{1} \mathrm{~B}_{2}\right)$ & $\left(\mathrm{A}_{2} \mathrm{~B}_{2}\right)$ & $\left(\mathrm{A}_{3} \mathrm{~B}_{2}\right)$ \\
Kinestetik $\left(\mathrm{B}_{3}\right)$ & $\left(\mathrm{A}_{1} \mathrm{~B}_{3}\right)$ & $\left(\mathrm{A}_{2} \mathrm{~B}_{3}\right)$ & $\left(\mathrm{A}_{3} \mathrm{~B}_{3}\right)$ \\
\hline Pulation in this research is all student of class X SMAN 11 Jambi city.
\end{tabular}

Table 3 Number of Students of Class X SMA 11 Jambi City

\begin{tabular}{lcc}
\hline No & Class & Number of Students \\
\hline 1 & XMIPA 1 & 35 \\
2 & XMIPA 2 & 33 \\
3 & XMIPA 3 & 35 \\
4 & X MIPA 4 & 33 \\
\hline \multicolumn{2}{l}{ Total } & 136 students \\
\hline
\end{tabular}

In this research, two groups of randomly selected samples were chosen from one group of experiments from study group using SAVI approach, SAVI + media approach and one control group that is learning group using direct instructional. In order to obtain a representative sample, steps are taken such as taking the monthly test scores, and doing normality and homogenity tests, as well as the average similarity. This study uses the help of SPSS 23. From the calculation, it can be concluded that the population has normal distributed data, has a homogeneous variance and does not have average difference, then to determine the sample class in the population used combination technique.

Statistical method used is hypothesis test with two way anova test. Before analyzing, first tested the normality and homogeneity test using SPSS 23. It was found that the post test data of the students were normal and homogeneous distributed. Furthermore, hypothesis testing using two way anova.

\section{RESULT AND DISCUSSION}

In this research is given questionnaire student learning style, in experiment class and control class. The learning style questionnaire aims to look at the trend of learning styles that each student has in both the experimental and control classes. Here are the 
results obtained from the learning style questionnaire that has been given to the experimental class and control class.

1. In the first experimental class there were 16 students with visual learning style, 7 students with audio learning style and 12 students with kinesthetic learning style

2. In the second experiment class there were 13 students with visual learning style, 14 students with audio learning style and 8 students with kinesthetic learning style

3. In the control class there were 11 students with visual learning style, 12 students with audio learning style and 10 students with kinestetik learning style

The results of students' mathematics learning acquired after the end of the tests given in class the first experiment, a second experiment class and control class. Here is the data of mathematics learning results of students class 10 presented in the following table:

Table 4 data result of learning mathematics class $\mathrm{X}$

\begin{tabular}{|c|c|c|c|c|c|c|c|}
\hline \multirow{2}{*}{\multicolumn{2}{|c|}{ Description }} & \multicolumn{2}{|c|}{$\begin{array}{l}\text { Experiment } \\
\text { Class } 1\end{array}$} & \multicolumn{2}{|c|}{$\begin{array}{c}\text { Experiment } \\
\text { Class } 2\end{array}$} & \multicolumn{2}{|c|}{ Control Class } \\
\hline & & Statistic & $\begin{array}{l}\text { Std. } \\
\text { Error }\end{array}$ & Statistic & $\begin{array}{l}\text { Std. } \\
\text { Error }\end{array}$ & Statistic & $\begin{array}{l}\text { Std. } \\
\text { Error }\end{array}$ \\
\hline Mean & & 82,09 & 0,815 & 82,2 & 0,815 & 77,42 & 0,919 \\
\hline $95 \%$ & Lower & 80,43 & & 80,54 & & 75,55 & \\
\hline Confidence & Bound & & & & & & \\
\hline Interval for & Upper & 83,74 & & 83,86 & & 79,3 & \\
\hline Mean & Bound & & & & & & \\
\hline \multicolumn{2}{|c|}{$5 \%$ Trimmed Mean } & 82,04 & & 82,17 & & 77,58 & \\
\hline \multicolumn{2}{|l|}{ Median } & 82 & & 82 & & 78 & \\
\hline \multicolumn{2}{|l|}{ Variance } & 23,257 & & 23,224 & & 27,877 & \\
\hline \multicolumn{2}{|c|}{ Std. Deviation } & 4,823 & & 4,819 & & 5,28 & \\
\hline \multicolumn{2}{|l|}{ Minimum } & 75 & & 75 & & 66 & \\
\hline \multicolumn{2}{|l|}{ Maximum } & 90 & & 90 & & 86 & \\
\hline \multicolumn{2}{|l|}{ Range } & 15 & & 15 & & 20 & \\
\hline \multicolumn{2}{|c|}{ Interquartile Range } & 6 & & 6 & & 8 & \\
\hline \multicolumn{2}{|l|}{ Skewness } & 0,068 & 0,398 & $-0,003$ & 0,398 & $-0,471$ & 0,409 \\
\hline \multicolumn{2}{|l|}{ Kurtosis } & $-0,777$ & 0,778 & $-0,774$ & 0,778 & $-0,241$ & 0,798 \\
\hline
\end{tabular}

Normality test aims to see whether the data is normally distributed or not. Test normality of postes value data using kolmogorov-smirnov test. The test results can be seen in the following table.

Table 5 Normality Test of Student Postes Value

\begin{tabular}{llrcc}
\hline \multirow{2}{*}{ Class } & \multicolumn{3}{c}{ Kolmogorov-Smirnov } \\
\cline { 2 - 5 } & Statistic & df & Sig. \\
\hline Value & Eksperimen1 &, 133 & 35 &, 123 \\
Eksperimen2 &, 132 & 35 &, 125 \\
Kontrol &, 151 & 33 &, 053 \\
\hline \multicolumn{2}{c}{110} & & &
\end{tabular}


Furthermore, the result of homogeneity test of students postes value where homogeneity test is aimed to see whether the student's postal value is homogeneous or not. The result of homogeneity test of students postes value with SPSS 23.0 program with the following result.

Table 6 Output SPSS 23.0 homogenity test results of students postes score

\begin{tabular}{rrrr}
\hline Levene Statistic & df1 & df2 & Sig. \\
\hline, 138 & 2 & 100 &, 871 \\
\hline
\end{tabular}

From the output can be seen the value of significance of the student postes value $=$ 0.871 or p-value $>$ alpha $=0.05$. Then it can be concluded that the data value of postes students homogeneous. Furthermore, hypothesis testing will be done using Two Path Analysis (Two Way Anova) and Tukey test. The following is presented the results of data analysis using Two Way Anova analysis to test the research hypothesis is as follows:

Table 7 results of data analysis using Two Way Anova analysis

\begin{tabular}{lrrrrr}
\hline & \multicolumn{1}{c}{$\begin{array}{c}\text { Type III } \\
\text { Sum of }\end{array}$} & & & & \\
Source & \multicolumn{1}{c}{ Squares } & Df & Mean Square & \multicolumn{1}{c}{ F } & Sig. \\
\hline Corrected Model & $2257,050^{\mathrm{a}}$ & 8 & 282,131 & 37,095 &, 000 \\
Intercept & 620019,387 & 1 & 620019,387 & 81520,959 &, 000 \\
Modelpembelajaran & 381,982 & 2 & 190,991 & 25,112 &, 000 \\
GayaBelajar & 1673,017 & 2 & 836,509 & 109,985 &, 000 \\
Modelpembelajaran & 77,111 & 4 & 19,278 & 2,535 &, 045 \\
$*$ GayaBelajar & 714,931 & 94 & 7,606 & & \\
Error & 672613,000 & 103 & & & \\
Total & 2971,981 & 102 & & & \\
\hline Corrected Total & & & & &
\end{tabular}

Next, a follow-up tests is done to determine which ones make the average mathematics student learning outcomes different. The method used for the follow-up test is the Tukey test. The Tukey test results are presented in the following table:

Table 8 Tukey test results

\begin{tabular}{ccccccc}
\hline & & & & \multicolumn{3}{c}{$95 \%$ Confidence } \\
Interval
\end{tabular}


Based on the above table, it can be seen that the p-value at Direct Instructional toward SAVI approach and SAVI + media approach are 0.000 and 0,000 respectively compared to the alpha value 0.05 then the $\mathrm{p}$-value is smaller than the alpha value.

Classes with SAVI approach to SAVI + media and direct instructional approach obtained p-value values of 0.984 and 0.000 respectively. when compared with the aplha value of 0.05 then the p-value for the SAVI approach class against the Direct Instructional approach is smaller than the alpha value $(0,000<0.05)$ and when compared with the alpha value of 0.05 then the p-value for the class approach SAVI against SAVI + media approach is greater than alpha value $(0.984>0.05)$. if the class of SAVI and SAVI + approach of media compared with direct instructional hence can be concluded that there is difference of mean of the mathematics learning result of student class X SMAN 11 Jambi.

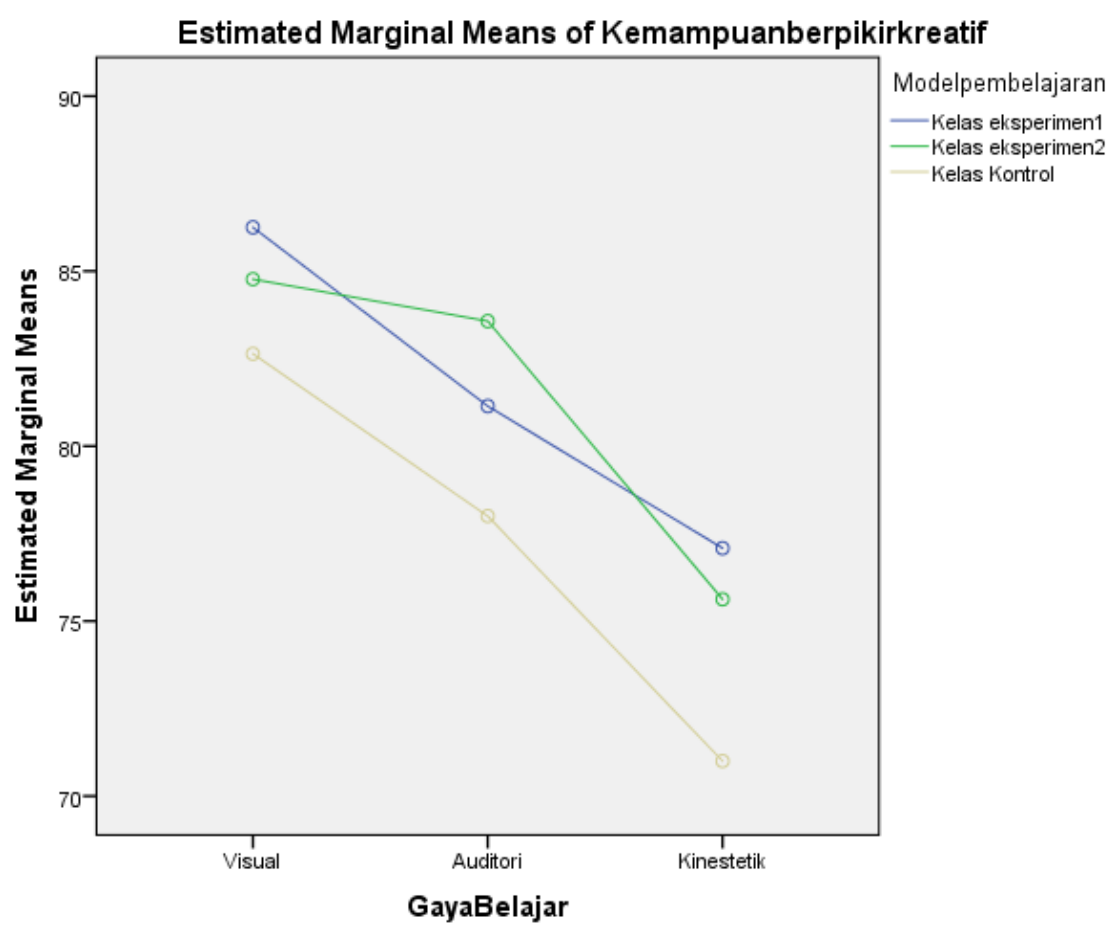

Figure 1 Sample Class Interactions

From the plot chart above shows that there is an interaction between the first experimental class and the second experimental class in influencing the student's mathematics learning outcomes. This is indicated by the existence of a tangent line.

After testing all four hypotheses. Then proceed with a further test. A further test is useful to know that the average of the class Which makes different students' ability to think creatively. The method used is tukey test. From the test, it can be concluded that in the experimental class 1 and the experimental class 2, there is no average difference. So it can be concluded that the application of SAVI approach has an effect on the students' creative thinking ability. This conclusion corresponds to the graph shown that there is an 
interaction between the experimental class 1 and the experimental class 2 in influencing students' cognitive thinking skills.

\section{CONCLUSION}

1. Based on the results of research that has been done, it can be concluded that:

2. There is influence of SAVI approach (Somatis, Auditori, Visual, Intellectual) and student learning styles together to the ability of creative thinking mathematics in the students of class X SMA Negeri 11 Kota JAMBI

3. There is a significant influence between SAVI approach (Somatis, Auditori, Visual, Intellectual) to the ability of creative thinking mathematics in the students of class X SMA Negeri 11 Kota JAMBI

4. There is influence of student's learning styles to the ability of creative thinking mathematics in class X students of SMA Negeri 11 Kota JAMBI

5. There is an interaction between SAVI approach (Somatis, Auditori, Visual, Intellectual) and learning style of students in influencing the ability of creative thinking mathematics in the students of class X SMA Negeri 11 Kota JAMBI

6. There is influence of visual learning style to student's creative thinking ability of mathematics.

7. There is an influence of auditory learning style on students' mathematical creative thinking ability.

8. There is an influence of kinesthetic learning style on students' creative thinking ability.

\section{SUGGESTION}

1. It is suggested to the teacher or further researcher if using SAVI approach (Somatis Auditori Visual Intellectual) on learning process to pay more attention to the activities of students in the group

2. If using the SAVI approach (Somatis Auditori Visual Intelektual) requires good planning with class management as well as the right time.

3. It is expected that further research can be done in a subject other than the subject of trigonometry.

4. In choosing a learning approach teachers need to consider the learning style of students, so that the learning approach used can make all students become comfortable in receiving classroom learning.

5. If you are going to apply the SAVI approach (Somatis Auditori Visual Intelektual), the teacher should be able to form a heterogeneous group division.

\section{REFERENCES}

Anas, Aswar dan Nilam Permatasari Mumir, 2014. Pengaruh Gaya Belajar VAK Terhadap Hasil Belajar Matematika Siswa, Soppeng: Jurnal Seminar Nasional ISSN 2443-1109 Volume 02, Nomor 1

Candra, Indrawan Dwi (2015) Pengaruh Gaya Belajar terhadap hasil belajar siswa kelas IV SD Negeri Pajang 3surakarta Tahun Ajaran 2014/2015. Skripsi thesis, Universitas Muhammadiyah Surakarta. 
Creswell, John. W. 2008. Educational Research Planning, Conducting And Evaluating Quantitative And Qualitative Research (Eds Thrid). Person Education, Inc. Upper Saddle River, New Jersey.

Dryden \& Jeannete, 2013. The Learning Revolution. Revolusi Cara Belajar, Bandung:Kaifa

Mahmudi, Ali, 2009. Mengembangkan kemampuan berpikir kreatif siswa melalui pembelajaran topik pecahan. Yogyakarta: Seminar Nasional Aljabar, Pengajaran, dan Terapannya di Jurusan Pendidikan Matematika FMIPA UNY Yogyakarta.

Meier, Dave, 2000. The Accelerated Learning Handbook. United states of America: McGraw-Hill Compaines

Prashing, Barbara. 2007. The Power Of Learning Styles, Bandung:Kaifa.

Sugiyono. 2009. Metode Penelitian Kuantitatif, kualitatif dan $R \& B$. Bandung: Alfabeta. 